\title{
Conceptual Designs for the AT-400MO Package
}

\author{
L. E. Fischer \\ R. F. Hafner \\ J. Hovingh \\ S. C. Keeton \\ E. W. Russell \\ J. Lemmings
}

January 1997

This is an infermal repect intended primarlly for intemal of limited external diveribution. The opinivas end concluaiens stated are theme of the author and may or may not be thone of the Laberabory.

Work performed under the aupices of the U.S. Department of Energy by the Lawrence Livermere Natbonal Laboratery under Contract W-7106-Eng-18. 


\section{DISCLAIMER}

This document was prepared as an account of work sponsored by an agency of the United States Government. Neither the United States Covernment nor the University of California nor any of their employees, makes any warranty, exprees or implied, or sesumes any legal liebility or responsibility for the sccurncy, completenese, or vecfulness of any information, apparatus, product, or process disclosed. oc represents that ts use would not infringe privately ownod rights. Reference herein to any specific commercial product, process, or service by trade name, trademark, manufacture, or otherwise, does not necesently conotitute or imply its endorsement, recommendation, or favoring by the United States Covernment or the University of Californin. The views and opinions of authors expresed herein do not necesearily state or reflect those of the United States Government or the University of California, and shall not be used for advertieing or product endorsement purposes.

This report has been reproduced directly from the best available copy.

Available to DOE and DOR contractors from the Office of Scientific and Technical Information P.O. Box 62, Oak Ridge, TN 37831

Prices aveilable from (615) 576-8101, FTS 626-8401

Available to the public from the National Techrical Information Service

U.S. Department of Commerce

5285 Port Royal Rd.

Springfield, VA 22161 


\section{Conceptual Designs for the AT-400MO Package}

Prepared by

J. Lemmings

Mason and Hanger - Silas Mason Co., Inc.

L.E. Fischer

R.F. Hafner

J. Hovingh

S.C. Keeton

E.W. Russell

Lawrence Livermore National Laboratory

Prepared for

Mason and Hanger - Silas Mason Co., Inc.

Amarillo, Texas 


\begin{abstract}
Currently, Pantex handles and stores weapon pits in AT-400A packages. The Department of Energy (DOE) currently plans to oversee the conversion of weapon pits into plutonium metal or oxide. These products will then be stored, and perhaps transported at a later time, to other DOE sites. If DOE assigns the pit conversion process to Pantex, it makes sense to store the resulting $\mathrm{Pu}$ metal or oxide at Pantex, utilizing existing facilities, equipment, processes, and personnel.

The four conceptual designs presented herein substitute the current AT-400A containment vessel, designed for weapon pits, with a vessel designed to store and/or ship Pu metal or oxides. These new designs utilize the existing AT-400A overpack system-consisting of the drum assembly and radial impact limiters-and likewise employ existing AT $-400 \mathrm{~A}$ production operations, e.g., handling, loading, unloading, and leakage testing.
\end{abstract}




\section{Table of Contents}

..vii

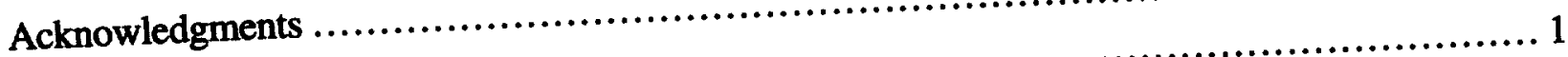

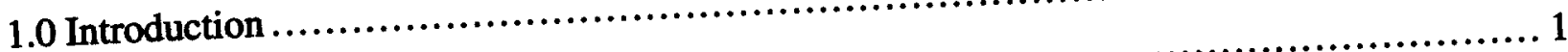

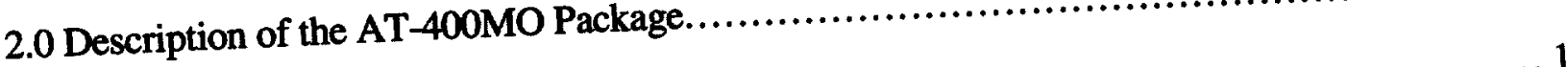

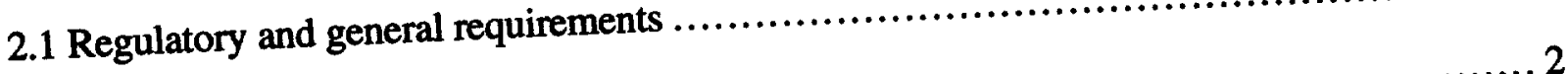

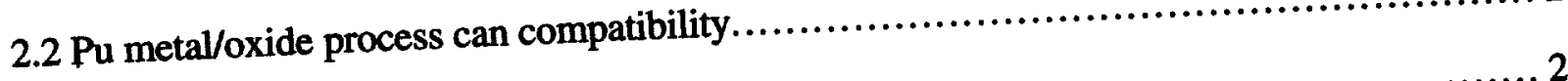

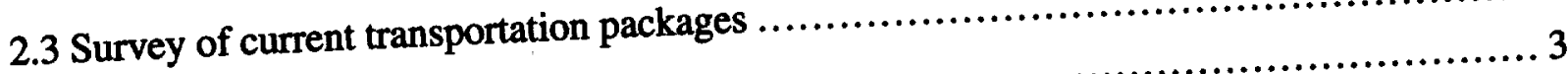

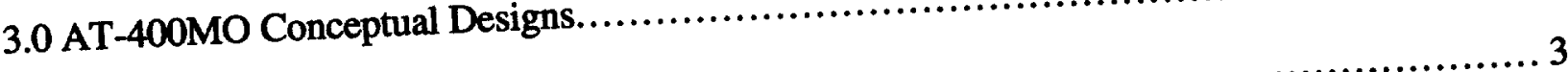

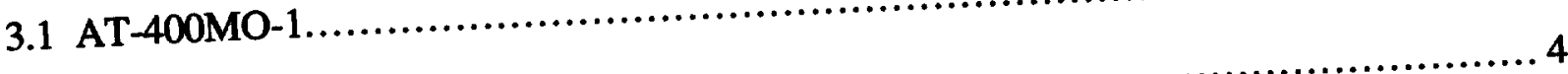

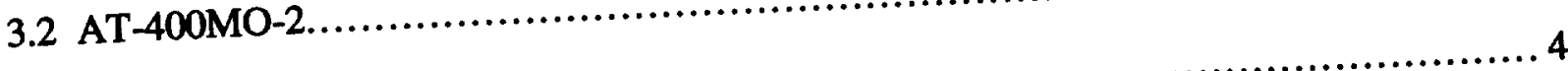

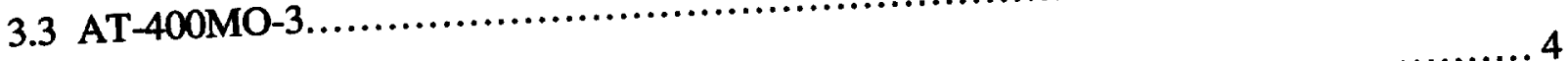

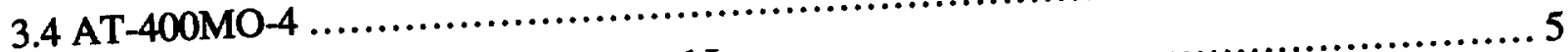

4.0 AT-400MO Operational Description and Issues ........................ 5

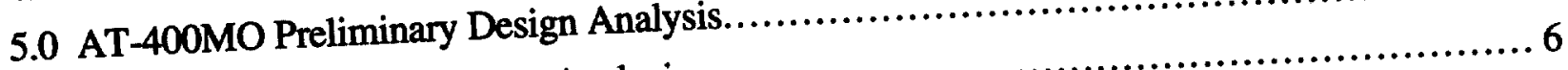

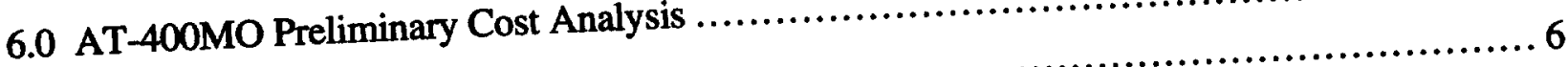

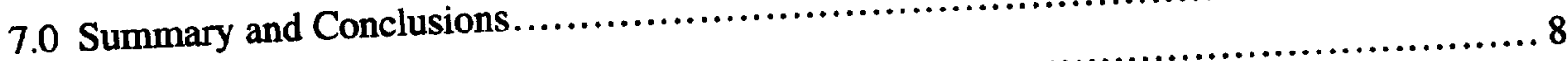

References

\section{Tables}

Table 1. Storage at Pantex DOE-STD-3013-96 Storage Requirements...

Table 2. AT-400MO General Requirements for AT-400MO Storage and/or

Transport Package

Table 3. Plutonium/Uranium Transport Packagings Currently in Use, Undergoing

Certification or Re-Certification

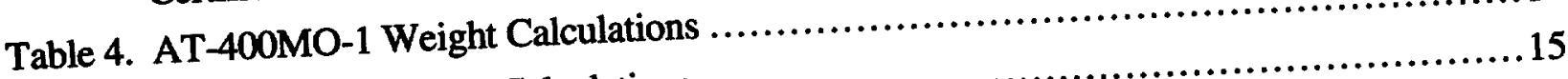

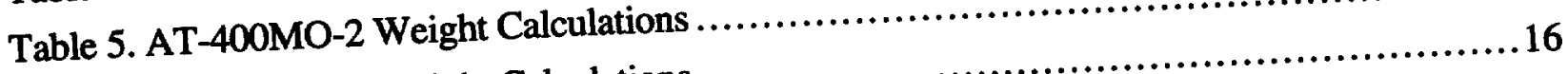

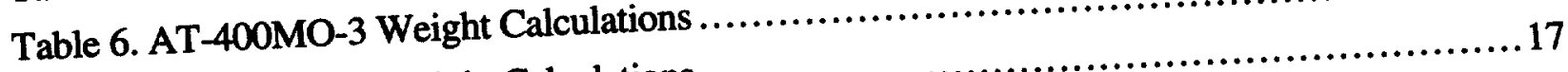

Table 7. AT-400MO-4 Weight Calculations 


\section{Figures}

Figure 1. AT-400 Container...................................................... 18

Figure 2a. AT-400MO-1 Storage Packaging..........................................19

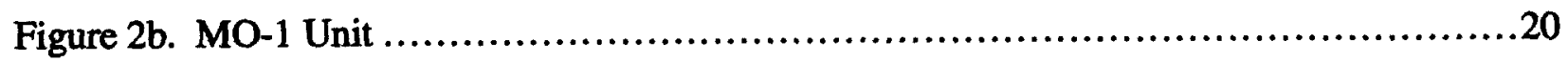

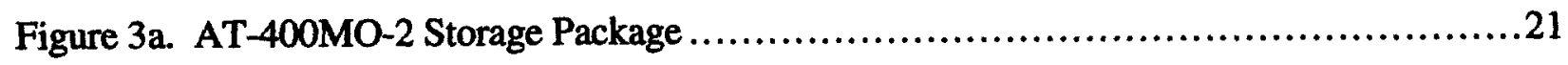

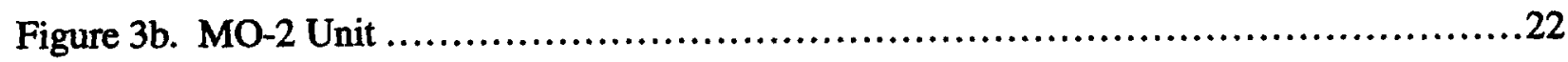

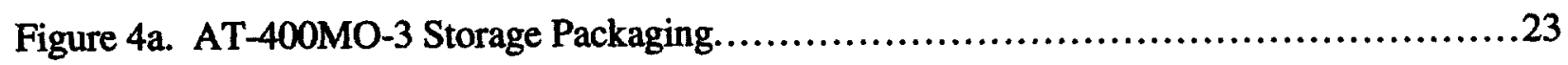

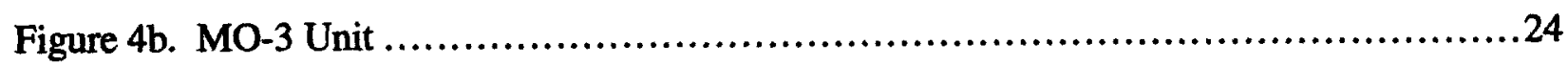

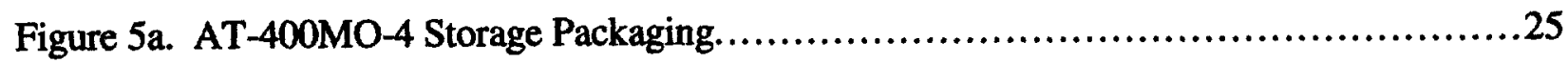

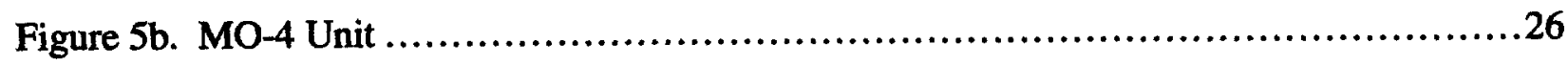




\section{Acknowledgments}

This work was sponsored by Mason and Hanger-Silas Mason Co., Inc. The Technical Manager was Henry King who provided guidance on which storage and transport options to evaluate. Joel Watkins prepared the drawings for the four conceptual design options. Special thanks to Shelli Neal for her administrative support and to Lyssa Campbell for editing. 


\subsection{Introduction}

The United States is currently embarking on an aggressive program to dismantle a portion of the nuclear weapons stockpile and dispose of or store the recovered nuclear materials. This dismantlement activity is carried out by Pantex in Amarillo, Texas. Currently, Pantex handles and stores weapon pits in AT-400A packages. The Department of Energy (DOE) currently plans to oversee the conversion of excess weapon pits into plutonium (Pu) metal or oxide. These products will then be stored, and perhaps transported at a later time, to other DOE sites. If DOE assigns the pit conversion process to Pantex, it makes sense to store the resulting Pu metal or oxide at Pantex, utilizing existing facilities, equipment, processes, and personnel.

The three conceptual designs presented herein substitute the current AT-400A containment vessel (Figure 1), designed for weapon pits, with a vessel designed to store and/or ship Pu metal or oxides. These new designs utilize the existing AT-400A overpack systemconsisting of the drum assembly and radial impact limiters-and likewise employ existing AT-400A production operations, e.g., handling, loading, unloading, and leakage testing. This paper describes the design concepts for the primary and secondary containment vessel (PCV and SCV) for storing Pu in the form of metal or oxides.

The new containment vessel designs are completely compatible with AT-400A production facilities at Pantex, offering DOE the greatest amount of flexibility in transporting materials between sites. This compatibility allows Pantex to receive clean metals and oxides that have been packaged and transported in either (1) a complete storage/transport package, consisting of PCV/SCV units housed in the AT-400A overpack system, or (2) another licensed package, such as the Chalfant or Safekeg. All packages are in compliance with DOE-STD-3013-96[1]. The PCV/SCV units would then be placed in proposed Pantex warehouse storage systems.

\subsection{Description of the AT-400MO Package}

\subsection{Regulatory and general requirements}

Table 1 summarizes the major requirements for storing Pu metals and oxides as specified in DOE-STD-3013-96. Many of these requirements are compatible with transportation regulations specified in 10 CFR $71^{[2]}$. The most efficient package design will both store and transport $\mathrm{Pu}$ metal and oxides.

Table 2 summarizes the general requirements for a modified AT-400A package for storing, and possibly transporting, Pu metal and oxides. This package, called the AT-400MO, would use the AT-400A overpack system and be compatible with the AT-400A production facilities at Pantex. 


\subsection{Pu metal/oxide process can compatibility}

The PCV/SCV design will be compatible with the BNFL, Inc. Plutonium Stabilization and Package System with convenience cans (4.4-in. diameter, 8.4 in. tall), or other systems that use the "Tuna Can" (3.38-in. diameter, 2 in. tall) or "Tomato Can" (4-in. diameter, 4.6 in. tall) for transport in the DOE specification $6 \mathrm{M} / 2 \mathrm{R}$ packagings. The convenience cans utilize a sphincter seal (metal-to-metal closure), which can relieve possible pressure buildups. The Tuna and Tomato cans, on the other hand, utilize welded closures and would not relieve potential pressure build-ups. Although loading the convenience can into a PCV would require remote handling operations, the sphincter seal should have adequate reliability for routine operations. This operation is anticipated to be carried out in a "clean" glove-box system.

\subsection{Survey of current transportation packages}

Lawrence Livermore National Laboratory (LLNL) staff conducted a survey of the plutonium packagings (1) currently in use, (2) under recertification, and/or (3) in the process of being certified. The primary source of survey data was gathered through a search of the RAMPAC ${ }^{[3]}$ database. Additional data sources were from the information presented in NUREG $0383^{[4]}$ and from informal communications with personnel at DOE Headquarters and at DOE/AL. Packagings eliminated from the outset, on both a national and international basis, were those limited to the shipment of plutonium in Special Form, as defined in 10 CFR 71.4. The results of this survey are shown in Table 3.

An overview of these results shows that, with the exception of the 5320 and Mound $1 \mathrm{~kW}$ packagings-which are used primarily for the transport of plutonium-238-the only packagings currently certified for the transport of plutonium are the Chalfant 30 and the Chalfant 35. Also referred to as the 9965 and 9968 packagings, the former is certified for the transport of plutonium metal and the latter is certified for the transport of plutonium oxides and powders. The two different configurations of the same basic packaging design have been shown to be in full compliance with the single-containment vs. doublecontainment requirements specified in 10 CFR 71.63.

Technically, the 9965 and 9968 packagings are in the process of being recertified. They are, however, the only packagings that can be used because, for the most part, the other packagings listed in Table 3 (i.e., the 9972, 9973, 9974, and 9975 packagings, the Safekeg 2863B packaging, and the AT-400A, AT-400B, and AT-400R packagings) have yet to be certified.

The DOT Specification 6M/2R packagings in 15-, 30-, 55-, and 110-gallon drum configurations also listed in Table 3 are shown for completeness. In general, these packagings provide single containment and cannot be leak checked to ANSI N15.4 therefore they were eliminated from further consideration. 


\subsection{AT-400MO Conceptual Designs}

The design bases for the AT-400MO include:

- DOE-STD-3013-96 for storage

- 10 CFR 71 for transport

- ASME Boiler and Pressure Vessel Code (B\&PVC), Section III, Subsection NB ${ }^{[5]}$.

The latter is the NRC-recommended National Standard for design/fabrication quantitative acceptance criteria to meet the safety requirements of 10 CFR 71 for Type-B packages. Three AT-400MO design concepts were prepared and evaluated using the general requirements of Table 2, and will accommodate one to three convenience cans with the AT400A overpack system.

\subsection{AT-400MO-1}

The first AT-400MO conceptual design (AT-400MO-1) meets or exceeds all of the requirements of DOE-STD-3013-96 and Table 2, but is for storage only. Both the PCV and SCV can be transported as an MO-1 unit in Chalfant or Safekeg transport packagings. Prior to transport, an MO-1 storage unit has to be removed from the AT-400MO-1 package and placed into a Chalfant or Safekeg package for transport. Only one MO-1 storage unit can be shipped at a time in these existing transport packages.

The AT-400MO-1 storage-packaging design is shown in Figure $2 \mathrm{a}-\mathrm{b}$. Both the PCV and SCV are completely welded containment systems. The outer diameter of the SCV is 4.9 in. and the height is $10.0 \mathrm{in}$. A single unit consisting of the convenience can, PCV, and SCV will fit inside the AT-400A overpack system. An aluminum basket centers the single unit in the overpack and conducts heat to the overpack inner wall. After the PCV is put inside the SCV and the SCV is welded shut, the PCV can no longer be leak tested without cutting open the SCV. The MO-1 storage unit design, which uses completely welded containment systems, is recommended for transport in a separate certified transport packaging such as the Chalfant and Safekeg package. Because the walls of the PCV and SCV designs are relatively thin to meet geometry constraints, they may not be able to withstand all transport loading conditions alone, even with the AT- 400 overpack system. Also, prior to transporting, 10 CFR 71 requires leak testing of both containment vessels, which would require cutting open the SCV and then rewelding it shut after leak testing the PCV. If the Chalfant or Safekeg packaging is used, the leakage test would be performed on the transport package containment vessels which are sized to withstand all transport conditions. The AT-400MO-1 design has an overall weight of 257 pounds. The weight calculations are listed in Table 4. 


\subsection{AT-400MO-2}

The second conceptual design, AT-400MO-2, meets most of the requirements of DOESTD-3013-96. This design uses a bolted SCV with double seals and allows leak testing of both containment vessels for transport in the AT-400MO-2 packaging. This design does not meet the literal requirements of two welded closures implied in DOE-STD-3013-96, but meets its intent by using an equivalent design with two seals. The AT-400MO-2 storage and transport design is shown in Figure 3 a-b. The outer diameter of the SCV is $5.3 \mathrm{in}$. and the height is $12.0 \mathrm{in}$.

The bolted SCV in the AT-400MO-2 concept can accommodate a single welded PCV with a convenience can as shown in Figure 3b. Alternatively, the MO-1 storage unit shown in Figure $2 \mathrm{~b}$ can be accommodated in the SCV this allows flexibility in meeting storage and transportation requirements with either a double or triple containment system. The conceptual design shown in Figure $3 \mathrm{a}-\mathrm{b}$ uses a bore seal design. Alternatively, a flat face seal design can be used and still meet all weight and geometry constraints. The total weight of the AT-400MO- 2 concept does not exceed $273 \mathrm{lbs}$. The weight calculations are listed in Table 5.

\subsection{AT-400MO-3}

The third conceptual design, AT-400MO-3 is similar to the AT-400MO-2 design but has twice the payload capacity. This design stacks either two welded PCVs or two MO-1 storage units on top of each other inside of a single bolted SCV. The conceptual design shown in Figure $4 \mathrm{a}-\mathrm{b}$ uses a flat face seal design. The maximum weight of the AT-400MO-3 is $318 \mathrm{lbs}$. The weight calculations are listed in Table 6. The maximum heat flux is 20 watts.

\subsection{AT-400MO-4}

The fourth conceptual design, AT-400MO-4 is also similar to the AT-400MO-2 design but has three times the payload capacity. This design arranges three bolted SCV in a symmetrical pattern shown in Figure 5 a-b. Each SCV contains either a welded PCV or a MO-1 storage unit. This design can use only a bore seal design for the SCV because of weight and geometry constraints. The design also requires the use of neutron poisons to maintain subcriticality with $a k_{\text {eff }} \leq 0.95$ for all conditions. The maximum weight of the AT-400MO-4 is 358 pounds, which slightly exceeds the 350 pounds design limit the weight calculations are listed in Table 7 . The maximum heat flux is 30 watts, which exceeds the 20 watts limit on the AT- 400 A package. 


\subsection{AT-400MO Operational Description and Issues}

The process requirements for compatibility with the BNFL system are summarized in the following steps for loading a convience into a MO-1 storage unit:

(1) Load convenience can into helium-filled PCVs in glove box, and perform closure weld.

(2) Perform leak check of PCV.

(3) Load PCV into helium-filled SCV and perform mechanical closure.

(4) Perform leak-check and contamination-check on SCV.

(5) Dispatch the storage systems to proposed Pantex warehouse storage system.

The operational details for the above process will be developed after a preliminary design has been completed and chosen.

\subsection{AT-400MO Preliminary Design Analysis}

The AT-400A overpack system should adequately protect the contents under all accident and transport conditions for the AT-400MO-2 through -4 designs. Accident analyses for transport will be performed after a preliminary design has been prepared.

Criticality safety, thermal, pressure, and stress analyses were performed on the AT400MO-1 through AT-400MO-4 packaging configurations for normal storage conditions. The simplified analyses indicate that the conceptual designs are feasible.

The most limiting cases for the criticality, thermal, pressure and stress analyses were for the AT-400MO-4 package which will be described.

The simplified nuclear criticality model used for the calculations ignored any steel material in the cans or containers and used either a homogeneous mixture of $5.1 \mathrm{~kg}$ of $\mathrm{PuO}_{2}$ or 4.5 $\mathrm{kg}$ of Pu metal with water to completely fill PCV or a $4.5 \mathrm{~kg}$ Pu metal sphere or metal wedge in most reactive location with water in each PCV. The entire triangular arrangement of the convenience cans for the AT400MO-4 design was surrounded with $30 \mathrm{~cm}$ of water to provide a fully water reflected boundary. The $\mathrm{K}_{\text {eff }}$ for this configuration is less than 0.95 , but requires the use of neutron poisons in the design. Infinite three dimensional square lattices of this AT400MO-4, with each PCV containing a $4.5 \mathrm{~kg}$ Pu metal sphere in most reactive location, gave a $\mathrm{K}_{\mathrm{eff}}$ less than 0.95 . 
The simplified thermal analysis used the characteristics of the AT-400A overpack system to estimate its inner wall temperature at $92^{\circ} \mathrm{C}$. The heat flow was assumed to be by contact in only the 6061-T6 aluminum basket. The maximum temperature calculated for the commercial can was $147^{\circ} \mathrm{C}$.

The water vapor desorbed from the plutonium oxide will cause most of the pressure in the primary containment vessel. Assuming that the temperature of the water vapor is at the temperature of the convenience can, the saturation pressure at $147^{\circ} \mathrm{C}$ is $64.6 \mathrm{psia}$ ( $50 \mathrm{psig}$ ).

For a primary storage containment vessel with a diameter of $4.7 \mathrm{in.}$ and a wall thickness of 0.12 in., the maximum stress from a pressure difference of $50 \mathrm{psi}$ is about $18000 \mathrm{psi}$ in the bottom flat plate. This stress is acceptable for most stainless steels at $147^{\circ} \mathrm{C}$.

\subsection{AT-400MO Preliminary Cost Analysis}

The following discussion involves evaluation of the AT-400MO conceptual design production costs based on a total capacity of 10,000 to 20,000 packages. The manufacturing processes that were evaluated are consistent with functional and performance requirements allotted to each packaging component. It was assumed that qualification of all fabrication contractors and subcontractors would be required per an ASME NQA-1 type quality assurance program, and the technical requirements would be dictated by the ASME Boiler and Pressure Code, Section III, Subsection NB for containment-related components and Subsection NF (Reference 6) or equivalent for other safety-related features. These cost estimates are "ballpark;" the final packaging cost presented here reflects an uncertainty range of roughly $200 \%$. The following are the packaging costs for the three conceptual designs:

\begin{tabular}{lll} 
(1) & AT-400MO-1 & $\$ 2.3 \mathrm{~K}$ \\
\hline (2) & AT-400MO-2 & $\$ 3.1 \mathrm{~K}$ \\
\hline (3) & AT-400MO-3 & $\$ 4.9 \mathrm{~K}^{*}$ \\
\hline (4) & AT-400MO-4 & $\$ 6.4 \mathrm{~K}$ \\
\hline
\end{tabular}

\subsection{Summary and Conclusions}

Conceptual designs were developed for the storage and transport of $\mathrm{Pu}$ in the form of metal or oxides at Pantex, utilizing existing facilities, equipment, processes and personnel as much as possible. The conceptual designs are completely compatible with the AT-400A production operations and would utilize the AT- $400 \mathrm{~A}$ overpack system.

*Based on two MO-1 storage units inside SCV 
The concepts meet the overall storage requirements of DOE-STD-3013-96 and the transportation requirements of 10 CFR 71. Criticality safety, thermal, pressure and stress analyses were performed on the AT-400MO packaging configurations for normal storage conditions. These simplified analyses indicate that these conceptual designs are feasible. PCV and SCV design/fabrication processes are specified to meet the requirements of the ASME Boiler and Pressure Vessel Code, Section III, Subsection NB, which is the NRCrecommended National Standard for design/fabrication quantitative acceptance criteria for Type-B packages. The AT-400MO-3 storage/transport package has two times the capacity of existing transportation packages. The AT-400MO-2 packaging is expected to cost approximately the same amount per packaging as existing transport packagings. 


\section{References}

1. U.S. Department of Energy. Criteria for Packaging of Plutonium Metals and Oxides for Long-Term Storage. DOE-STD-3013-96.

2. U.S. Code of Federal Regulations. "Packaging and Transportation of Radioactive Material." Title 10, Part 71. Washington, DC, April 1, 1996.

3. Analysas Corporation. Radioactive Materials Packages (RAMPAC) Database, User's Manual. Revised October 24, 1994.

4. U.S. Nuclear Regulatory Commission. Director of Certificates of Compliance for Radioactive Materials Packages. Certificates of Compliance. NUREG-0383, Volume 2, Revision 18, October 1995.

5. American Society of Mechanical Engineers. Boiler and Pressure Vessel Code. Section III, Division 1, Subsection NB, "Class 1 Components." New York.

6. American Society of Mechanical Engineers. Boiler and Pressure Vessel Code. Section III, Division 1, Subsection NF, “Component Supports." New York. 


\section{Table 1. Storage at Pantex DOE-STD-3013-96 Storage Requirements}

- Corrosion-resistant PCV/SCV material

- Two welded leaktight containment vessels

- Stabilizing atmosphere

- Leak-tightness per ANSI N14.5 after drop test

- Non-Destructive Assay (NDA), material verification, and inspection and surveillance

- Permanent identification

- Designed and proof-tested to 1.5 times the calculated theoretical maximum internal pressure

- Free of combustible or organic material

- Nondestructive indication of an internal pressure buildup at less than $690 \mathrm{kPa}(100$ psig)

- Material properties:

- thermal output of less than 30 Watts

- for metal, quantity $<4.4 \mathrm{~kg}$

- for oxides, quantity $<5.0 \mathrm{~kg}$

- Use existing Pu transport packages

- 4.9-in. outer diameter for secondary containment vessel

- 10.0-in. length for secondary containment vessel 
Table 2. AT-400MO General Requirements for AT-400MO Storage and/or Transport Package

- Compatible with all AT-400A operations

- Weight compatible with AT-400A weight limitation of 350 pounds

- Dimensional limitations per inside contour of AT-400A overpack and subcriticality requirements

- PCV/SCV design life: minimum of 50 years

- Weapons grade plutonium only

- Tamper detection mechanism

- PCV/SCV design and fabrication per the ASME Boiler and Pressure Vessel Code, Section III

- Quality Assurance/Quality Control per QC-1; 10 CFR 71, Subpart H and DOE-STD3013-96

- Compatible with the BNFL Plutonium Stabilization and Package System convenience cans or equivalent

- 4.4-in. inner diameter for primary containment vessel

- 8.4-in. inner length for primary containment vessel

- Complies with DOE-STD-3013-96 (Table 1)

- Equivalent bolted closure with two seals for secondary containment allowed

- Compatible with existing transport packages as alternates

- Complies with 10 CFR 71 
Table 3. Plutonium/Uranium Transport Packagings Currently in Use, Undergoing Certification or Re-Certification Complied by: R.S. Hafner, LLNL/FESSP

\begin{tabular}{|c|c|c|c|c|c|c|c|c|c|c|c|}
\hline $\begin{array}{l}\text { Package id } \\
\text { Number }\end{array}$ & $\begin{array}{l}\text { Generlc } \\
\text { Name }\end{array}$ & $\begin{array}{l}\text { Certifying } \\
\text { Agency }\end{array}$ & $\begin{array}{c}\text { Containment } \\
\text { System }\end{array}$ & $\begin{array}{c}\text { Generlc } \\
\text { Package } \\
\text { Description }\end{array}$ & $\begin{array}{c}\text { Overal } \\
\text { I } \\
\text { Helght } \\
\text { (In.) }\end{array}$ & $\begin{array}{c}\text { Overall } \\
\text { Dlameter } \\
\text { (In.) }\end{array}$ & $\begin{array}{c}\text { Groses } \\
\text { Welght } \\
\text { (lbs.) }\end{array}$ & $\begin{array}{l}\text { Allowable } \\
\text { Contente }\end{array}$ & $\begin{array}{l}\text { Maximum } \\
\text { Payload } \\
\text { (Watts) }\end{array}$ & \begin{tabular}{|c|} 
Maximum \\
Plutonium \\
Payload (grams)
\end{tabular} & Comments \\
\hline N/A & DOT-6M/2R & DOT/DOE & Single & 15-Galion Drum & 26.9 & 14.9 & 160 & $\begin{array}{l}\text { Pu-238 } \\
\text { Capsules; } \\
\text { Plutonium } \\
\text { Metal, } \\
\text { Ceramics, \& } \\
\text { Oxides }\end{array}$ & 10 & $\begin{array}{c}\text { See DOE/RL-94-68, } \\
\text { Sections } 5.0 \text { and } \\
18.0\end{array}$ & Currently in Use \\
\hline N/A & DOT-6M/2R & DOT/DOE & Single & 30-Gallon Drum & 29.1 & 19.6 & 480 & $\begin{array}{c}\text { Plutonium } \\
\text { Metal, Alloys \& } \\
\text { Oxides; } \\
\text { Uranium Metal } \\
\text { \& Compounds }\end{array}$ & 10 & $\begin{array}{c}\text { See DOE/RL-94-68, } \\
\text { Sections } 11.0 \\
\text { through } 15.0\end{array}$ & Currently in Use \\
\hline N/A & DOT-6M/2R & DOT/DOE & Single & 55-Gallon Drum & 34.8 & 23.9 & 640 & $\begin{array}{l}\text { Plutonium; } \\
\text { Uranium Metal, } \\
\text { Oxides \& } \\
\text { Compounds } \\
\end{array}$ & 10 & $\begin{array}{c}\text { Seө DOE/RL-94-68, } \\
\text { Sections } 9.0,11.0, \\
16.0 \text {, and } 19.0\end{array}$ & Currently in Use \\
\hline N/A & DOT-6M/2R & DOT/DOE & Single & $\begin{array}{l}\text { 110-Gallon } \\
\text { Drum }\end{array}$ & & & 640 & $\begin{array}{c}\text { Plutonium } \\
\text { Metal \& Oxide; } \\
\text { Uranium Metal, } \\
\text { Oxides \& } \\
\text { Compounds }\end{array}$ & 10 & $\begin{array}{c}\text { See DOE/RL-94-68, } \\
\text { Sections 5.0, 10.0, } \\
11.0 \text { and } 17.0\end{array}$ & Currently in Use \\
\hline USA5320/B( )F & 5320 & DOE & Double & $\begin{array}{l}\text { "R2D2" on } \\
\text { Rollers }\end{array}$ & 32.0 & 16.8 & 327 & $\begin{array}{l}\text { Plutonium } \\
\text { Oxides }\end{array}$ & 203 & 357 & $\begin{array}{c}\text { Currently in Use; } \\
\text { Recertification } \\
\text { Process in } \\
\text { Progress }\end{array}$ \\
\hline USA5320/B(M)F & $\begin{array}{c}\text { Replacement } \\
5320\end{array}$ & DOE & Double & $\begin{array}{l}\text { "R2D2" on } \\
\text { Rollers }\end{array}$ & 32.0 & 16.8 & 327 & $\begin{array}{l}\text { Plutonium } \\
\text { Oxides }\end{array}$ & 203 & 357 & $\begin{array}{l}\text { Replacement } \\
\text { Package; } \\
\text { Certification } \\
\text { Process in } \\
\text { Progress }\end{array}$ \\
\hline
\end{tabular}


Table 3. Plutonium/Uranium Transport Packagings Currently in Use, Undergoing Certification or Re-Certification, cont'd.

\begin{tabular}{|c|c|c|c|c|c|c|c|c|c|c|c|}
\hline $\begin{array}{l}\text { Package ID } \\
\text { Number }\end{array}$ & $\begin{array}{l}\text { Generic } \\
\text { Name }\end{array}$ & $\begin{array}{c}\text { Certifylng } \\
\text { Agency }\end{array}$ & $\begin{array}{c}\text { Containment } \\
\text { System }\end{array}$ & $\begin{array}{c}\text { Generlc } \\
\text { Package } \\
\text { Descrlption }\end{array}$ & $\begin{array}{l}\text { Overall } \\
\text { Height } \\
\text { (In.) }\end{array}$ & $\begin{array}{c}\text { Overall } \\
\text { Dlameter } \\
\text { (In.) }\end{array}$ & $\begin{array}{c}\text { Croses } \\
\text { Weight } \\
\text { (lbs.) }\end{array}$ & $\begin{array}{l}\text { Allowable } \\
\text { Contents }\end{array}$ & $\begin{array}{l}\text { Maximum } \\
\text { Payload } \\
\text { (Watts) }\end{array}$ & $\begin{array}{c}\text { Maximum } \\
\text { Plutonium } \\
\text { Payload (grams) }\end{array}$ & Comments \\
\hline $\begin{array}{l}\text { USA } 9516 / B(M) F- \\
85\end{array}$ & Mound $1 \mathrm{~kW}$ & DOT & Double & $\begin{array}{c}30.75 \text { in. } \times 30.75 \\
\text { in. } \times 35.25 \text { in. } \\
\text { Cage w/CV in } \\
\text { Bottom Center }\end{array}$ & 35.3 & $\begin{array}{c}30.75 \text { in. } x \\
30.75 \text { in. }\end{array}$ & 900 & Pu-238 Oxide & 500 & 1,000 & Currently in Use \\
\hline USA9516/B(U)F & Mound $1 \mathrm{~kW}$ & DOE & Double & $\begin{array}{c}30.75 \text { in. } \times 30.75 \\
\text { in. } \times 35.25 \text { in. } \\
\text { Cage w/CV in } \\
\text { Bottom Center }\end{array}$ & 35.3 & $\begin{array}{l}30.75 \text { in. } x \\
30.75 \text { in. }\end{array}$ & 900 & Pu-238 Oxide & 500 & 1,000 & Currently in Use \\
\hline $\begin{array}{c}\text { USA } 9516 / B(U) F- \\
85\end{array}$ & Mound $1 \mathrm{~kW}$ & DOT & Double & $\begin{array}{c}30.75 \text { in. } \times 30.75 \\
\text { In. } x 35.25 \text { in. } \\
\text { Cage w/CV in } \\
\text { Bottom Center }\end{array}$ & 35.3 & $\begin{array}{c}30.75 \text { in. } x \\
30.75 \text { in. }\end{array}$ & 900 & Pu-238 Oxide & 500 & 1,000 & Currently in Use \\
\hline USA9965/B(U)F & $\begin{array}{c}\text { Chalfant } 30 \\
\text { Single }\end{array}$ & DOE & Single & 30-Gallon Drum & 29.1 & 19.6 & 145 & $\begin{array}{c}\text { Pu-239 Metal; } \\
\text { U-235 } \\
\text { Metal/Oxide }\end{array}$ & 10 & 4,400 & $\begin{array}{c}\text { Currently in Use; } \\
\text { Recertification } \\
\text { Process in } \\
\text { Progress } \\
\end{array}$ \\
\hline USA $9968 / B(U) F$ & $\begin{array}{c}\text { Chalfant } 35 \\
\text { Double }\end{array}$ & DOE & Double & 35-Gallon Drum & 35.5 & 19.6 & 360 & $\begin{array}{c}\text { Pu-238 Oxide; } \\
\text { Pu-239 and U- } \\
235 \text { Oxide Mix; } \\
\text { Pu-239 Oxide } \\
\text { w/up to 5\% Am- } \\
241\end{array}$ & 18 & 4,300 & $\begin{array}{c}\text { Currently in Use; } \\
\text { Recertification } \\
\text { Process in } \\
\text { Progress }\end{array}$ \\
\hline USA9972/B(U)F & $\begin{array}{l}\text { Replace- ment } \\
\text { Chalfant } 30 \\
\text { Single }\end{array}$ & DOE & Single & 30-Gallon Drum & 29.1 & 19.6 & 145 & $\begin{array}{l}\text { Pu-239 Metal; } \\
\text { U-235 } \\
\text { Metal/Oxide }\end{array}$ & 11 & 4,400 & $\begin{array}{c}\text { Replacement } \\
\text { Pkg.; } \\
\text { Certification } \\
\text { Process in } \\
\text { Progress }\end{array}$ \\
\hline USA9973/B(U)F & N/A & DOE & Double & 30-Gallon Drum & 29.1 & 19.6 & 187 & $\begin{array}{l}\text { Pu-239 and U- } \\
235 \text { Oxide Mix }\end{array}$ & 13 & 4,400 & $\begin{array}{c}\text { Replacement } \\
\text { Pkg.; } \\
\text { Certification } \\
\text { Process in } \\
\text { Progress }\end{array}$ \\
\hline
\end{tabular}


Table 3. Plutonium/Uranium Transport Packagings Currently in Use, Undergoing Certification or Re-Certification, cont'd.

\begin{tabular}{|c|c|c|c|c|c|c|c|c|c|c|c|}
\hline $\begin{array}{l}\text { Package iD } \\
\text { Number }\end{array}$ & $\begin{array}{c}\text { Generic } \\
\text { Name }\end{array}$ & $\begin{array}{c}\text { Certifylng } \\
\text { Agency }\end{array}$ & $\begin{array}{c}\text { Contalnment } \\
\text { System }\end{array}$ & $\begin{array}{c}\text { Generic } \\
\text { Package } \\
\text { Description } \\
\end{array}$ & $\begin{array}{c}\text { Overall } \\
\text { Height } \\
\text { (In.) } \\
\end{array}$ & $\begin{array}{c}\text { Overall } \\
\text { Diameter } \\
(\text { In. })\end{array}$ & $\begin{array}{c}\text { Gross } \\
\text { Welght } \\
\text { (Ibs.) }\end{array}$ & $\begin{array}{l}\text { Allowable } \\
\text { Contente }\end{array}$ & $\begin{array}{l}\text { Maximum } \\
\text { Payload } \\
\text { (Watts) }\end{array}$ & $\begin{array}{c}\text { Maximum } \\
\text { Plutonlum } \\
\text { Payload (grams) }\end{array}$ & Comments \\
\hline USA/9974/B(U)F & N/A & DOE & Double & 55-Gallon Drum & 34.8 & 23.9 & 629 & $\begin{array}{l}\text { Pu-239 and U- } \\
235 \text { Oxide Mix }\end{array}$ & 14 & 4,400 & $\begin{array}{l}\text { Replacement } \\
\text { Package; } \\
\text { Certfication } \\
\text { Process in } \\
\text { Progress }\end{array}$ \\
\hline USA9975/B(U)F & $\begin{array}{c}\text { Peplace-ment } \\
\text { Chalfant } 35 \\
\text { Double }\end{array}$ & DOE & Double & 35-Gallon Drum & 35.5 & 19.6 & 360 & $\begin{array}{l}\text { Pu-238 Oxide; } \\
\text { Pu-239 and U- } \\
235 \text { Oxide Mix; } \\
\text { Pu-239 Oxide } \\
\text { w/up to } 5 \% \text { Am- } \\
241\end{array}$ & 19 & 4,300 & $\begin{array}{c}\text { Replacement } \\
\text { Package; } \\
\text { Certification } \\
\text { Process in } \\
\text { Progress }\end{array}$ \\
\hline USA $\quad / B(U)$ & $\begin{array}{c}\text { Safekeg } \\
2863 \mathrm{~B}\end{array}$ & DOE & Double & 30-Gallon Keg & 30.0 & 16.7 & 238 & $\begin{array}{l}\text { Pu-238 Oxide; } \\
\text { Pu-239 } \\
\text { Metal/Oxide; } \\
\text { and U-235 } \\
\text { Metal/Oxide }\end{array}$ & 40 & 9,000 & $\begin{array}{l}\text { New Package; } \\
\text { Certification } \\
\text { Process in } \\
\text { Progress }\end{array}$ \\
\hline USA $\quad \boldsymbol{B}(\mathrm{U})$ & AT- $400 \mathrm{~A}$ & DOE & Single & 30-Gallon Drum & 29.1 & 19.6 & 309 & $\begin{array}{l}\text { Weapons } \\
\text { Components }\end{array}$ & Classified & Classified & $\begin{array}{c}\text { New Package; } \\
\text { Certification } \\
\text { Process in } \\
\text { Process } \\
\end{array}$ \\
\hline USA $\quad \boldsymbol{B}(\mathrm{B})$ & AT-400B & DOE & Single & 30-Gallon Drum & 29.1 & 19.6 & 300 & $\begin{array}{l}\text { Weapons } \\
\text { Components }\end{array}$ & Classified & Classified & $\begin{array}{c}\text { New Package; } \\
\text { Design Process } \\
\text { in Progress }\end{array}$ \\
\hline N/A & AT $-400 R$ & N/A & Single & 30-Gallon Drum & 29.1 & 19.6 & 300 & $\begin{array}{l}\text { Weapons } \\
\text { Components }\end{array}$ & Classified & Classified & $\begin{array}{l}\text { DoD Package; } \\
\text { Bullt for use in } \\
\text { Russia; } \\
\text { Certification } \\
\text { Process Status } \\
\text { Unknown } \\
\end{array}$ \\
\hline N/A & $\begin{array}{c}3013 \\
\text { Standard } \\
\end{array}$ & N/A & Single & 30-Gallon Drum* & $29.1^{*}$ & $19.6^{*}$ & NA & Pu Metal & 30 & 4,500 & $\begin{array}{c}\text { Standard } \\
\text { Requirements }\end{array}$ \\
\hline NA & $\begin{array}{c}3013 \\
\text { Standard } \\
\end{array}$ & N/A & Double & 30-Gallon Drum* & $29.1^{*}$ & $19.6^{*}$ & N/A & Pu Oxide & 30 & 5,100 & $\begin{array}{c}\text { Standard } \\
\text { Requirements }\end{array}$ \\
\hline * Implied from Oth & Dimensions & & & & & & & & & & \\
\hline
\end{tabular}


Table 4. AT-400MO-1 Weight Calculations AT400MO-1: 1 CONVENIGNCE CAN IN 1 WELDED PRIMARY \& 1 WEIDED SECONDARY CONTAINER
WEIGHT CALCULATIONS

J.WATKINS 11-12-96

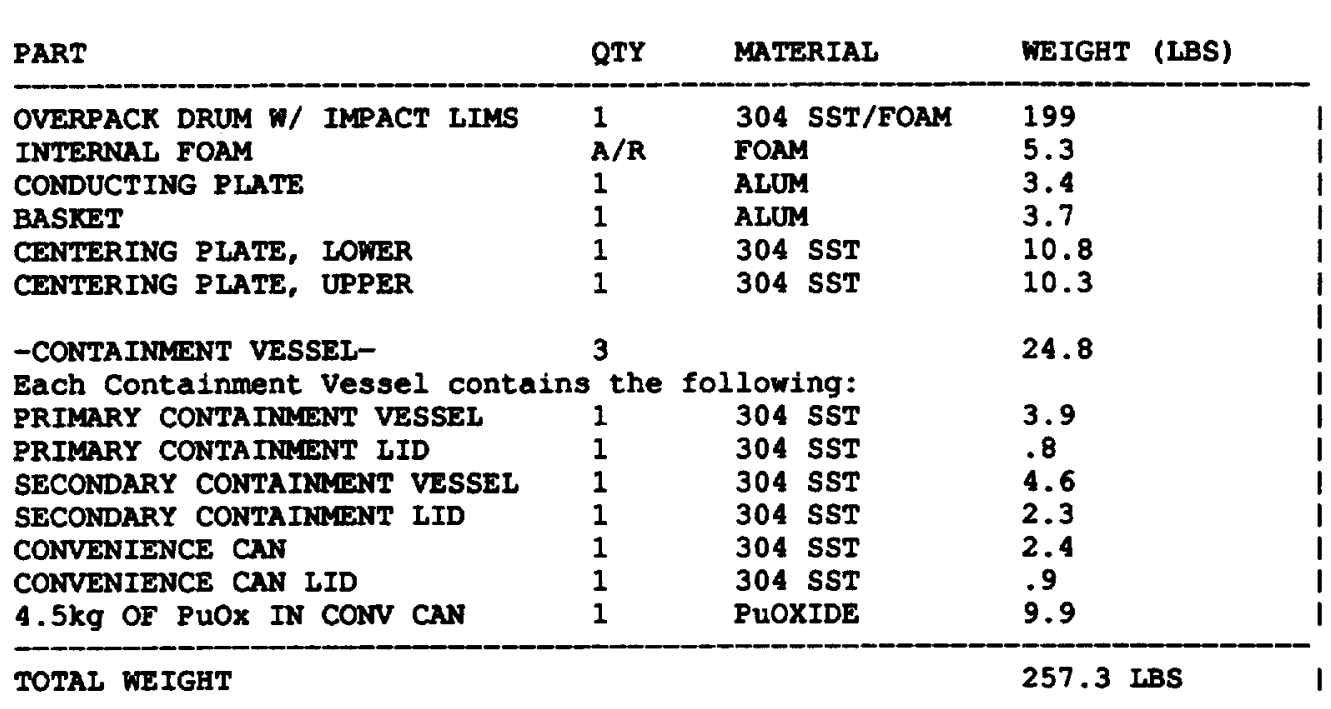

NOTES :

Overpack drum weight is estimated at 196 pounds including the 2 impact limiters shown in the AT-400A pit design. The impact limiters used for this weight calculation are $\mathbf{8 . 4 "}$ thick and their weight is estimated. 
Table 5. AT-400MO-2 Weight Calculations

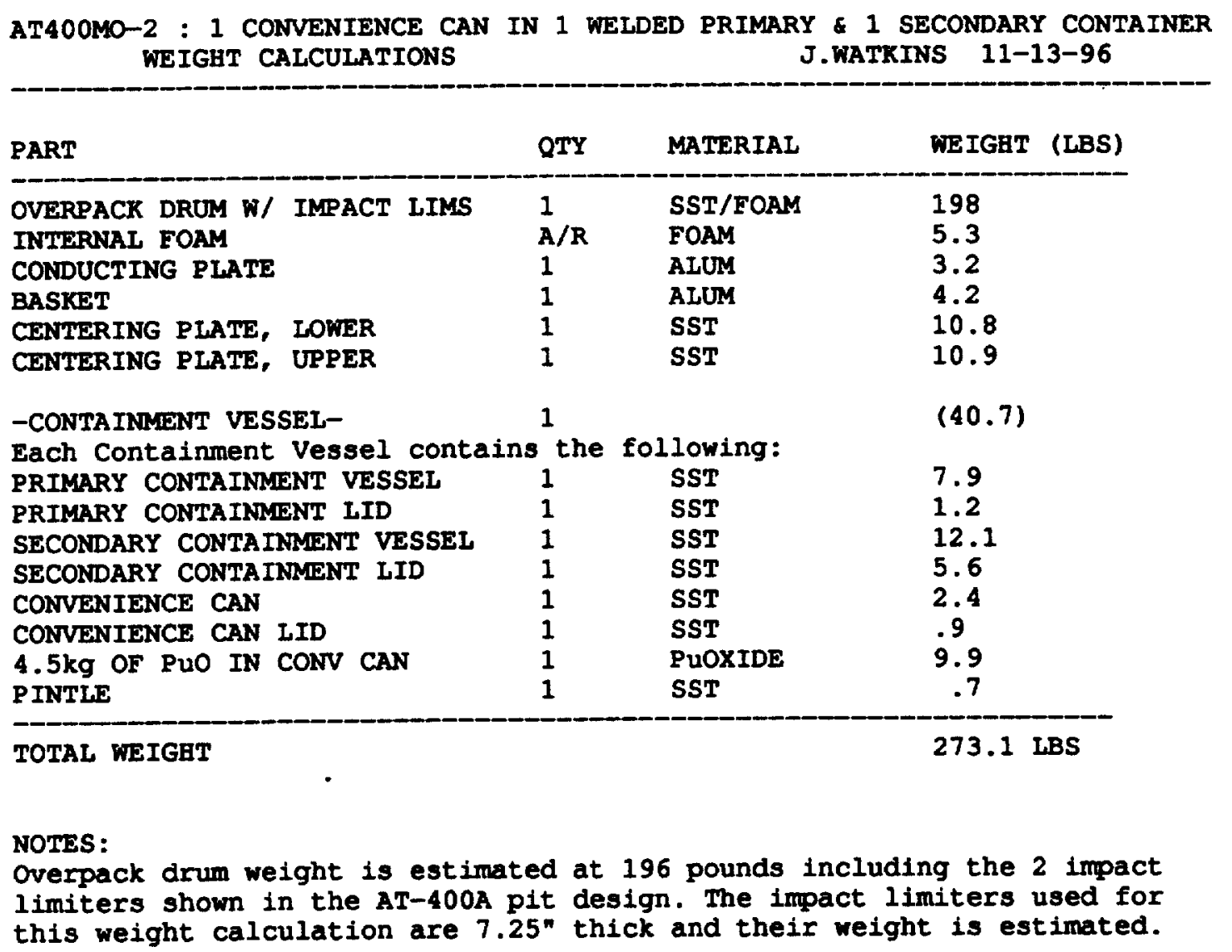


Table 6. AT-400MO-3 Weight Calculations

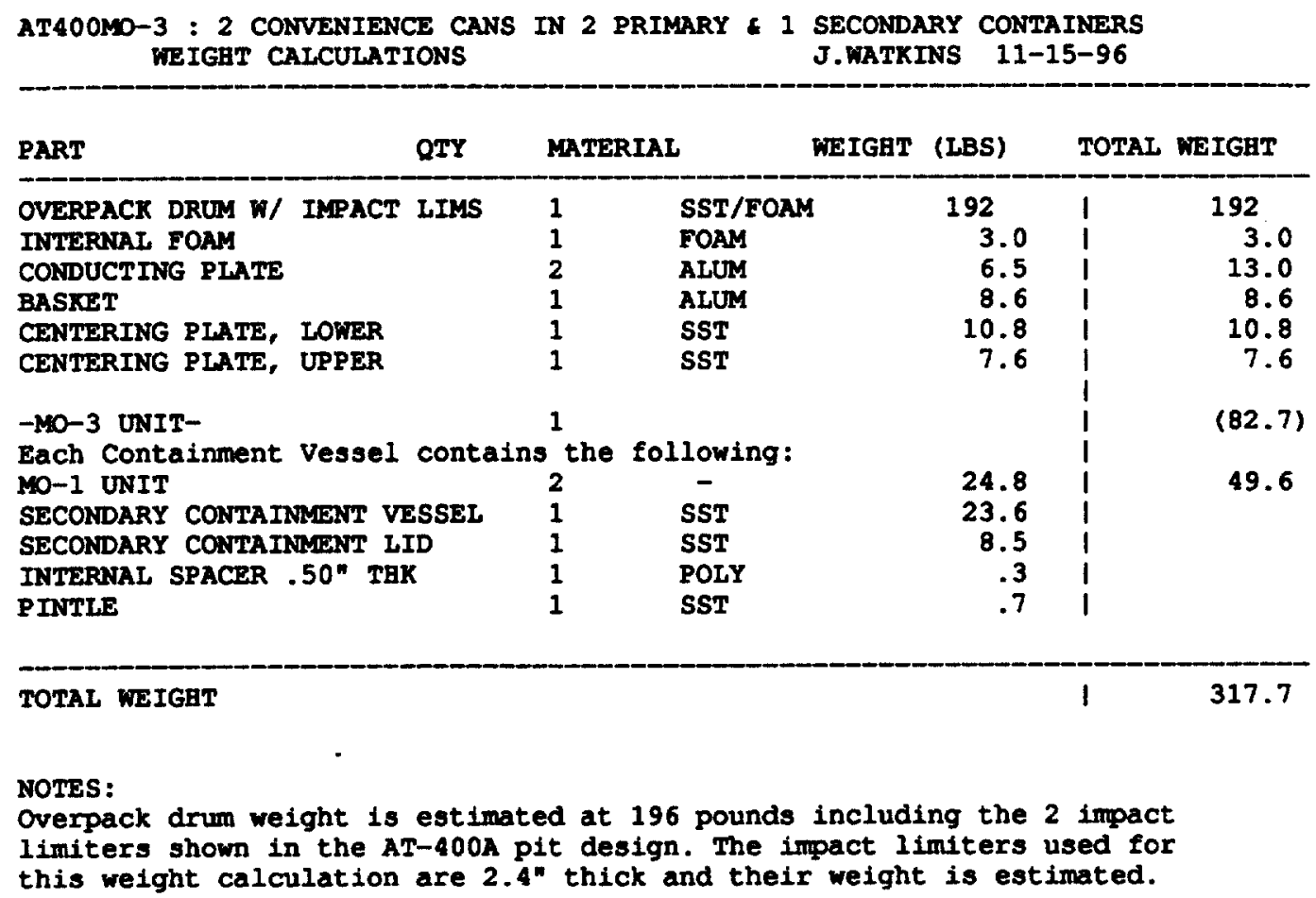


Table 7. AT-400MO-4 Weight Calculations

AT400MO-4: 3 CONVENIENCE CANS IN SINGLE PRIMARY - SECONDARY CONTAINERS

\begin{tabular}{|c|c|c|c|c|c|}
\hline PART & QTY & MATERIAL & MEIGHT & (LBS) & TOTAL \\
\hline 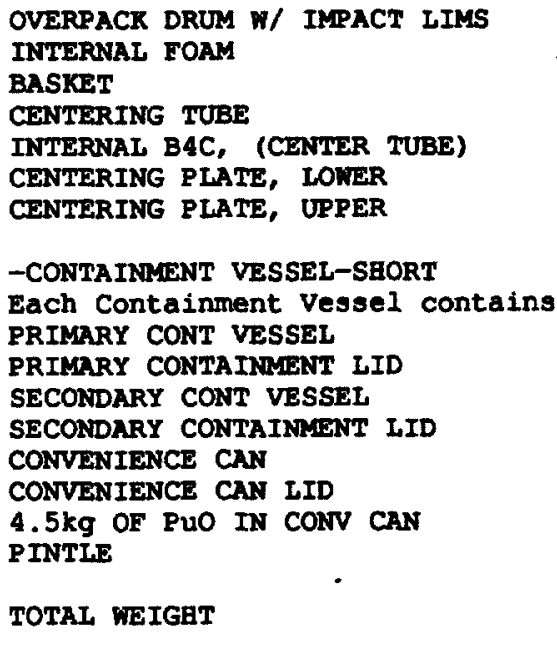 & $\begin{array}{l}1 \\
A / R \\
3 \\
1 \\
1 \\
1 \\
1 \\
3 \\
3 \\
1 \\
1 \\
1 \\
1 \\
1 \\
1 \\
1 \\
1\end{array}$ & $\begin{array}{l}\text { SST/FOAM } \\
\text { FOAM } \\
\text { ALUM } \\
\text { ALUM } \\
\text { BAC } \\
\text { SST } \\
\text { SST } \\
\\
\text { llowing: } \\
\text { SST } \\
\text { SST } \\
\text { SST } \\
\text { SST } \\
\text { SST } \\
\text { SST } \\
\text { PUOXIDE } \\
\text { SST }\end{array}$ & $\begin{array}{l}198 \\
3.0 \\
4.2 \\
0.5 \\
1.5 \\
10.3 \\
10.4 \\
40.7 \\
7.9 \\
1.2 \\
12.1 \\
5.6 \\
2.4 \\
.9 \\
9.9 \\
.7\end{array}$ & $\begin{array}{l}1 \\
1 \\
1 \\
1 \\
1 \\
1 \\
1 \\
1 \\
1 \\
1 \\
1 \\
1 \\
1 \\
1 \\
1 \\
1 \\
1 \\
1 \\
1 \\
1 \\
1\end{array}$ & $\begin{array}{l}198 \\
3.0 \\
12.6 \\
0.5 \\
1.5 \\
10.3 \\
10.4 \\
122.1\end{array}$ \\
\hline
\end{tabular}

NOTES:

Overpack drum weight is estimated at 196 pounds including the 2 impact limiters show in the AT-400A pit design. The impact limiters used for this weight calculation are $7.25^{\prime \prime}$ thick and their weight is estimated. 
Figure 1

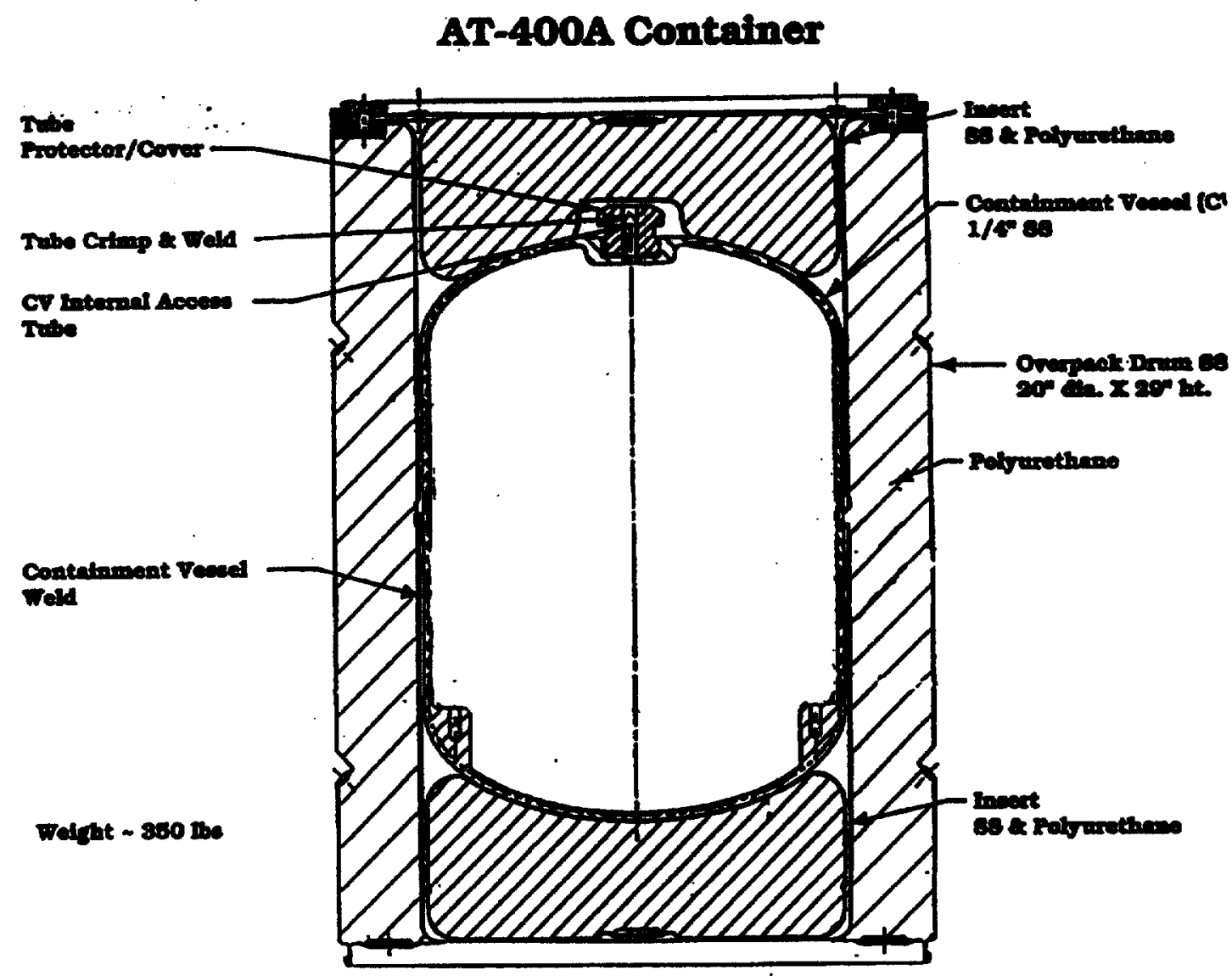


Figure 2a. AT-400MO-1 Storage Packaging
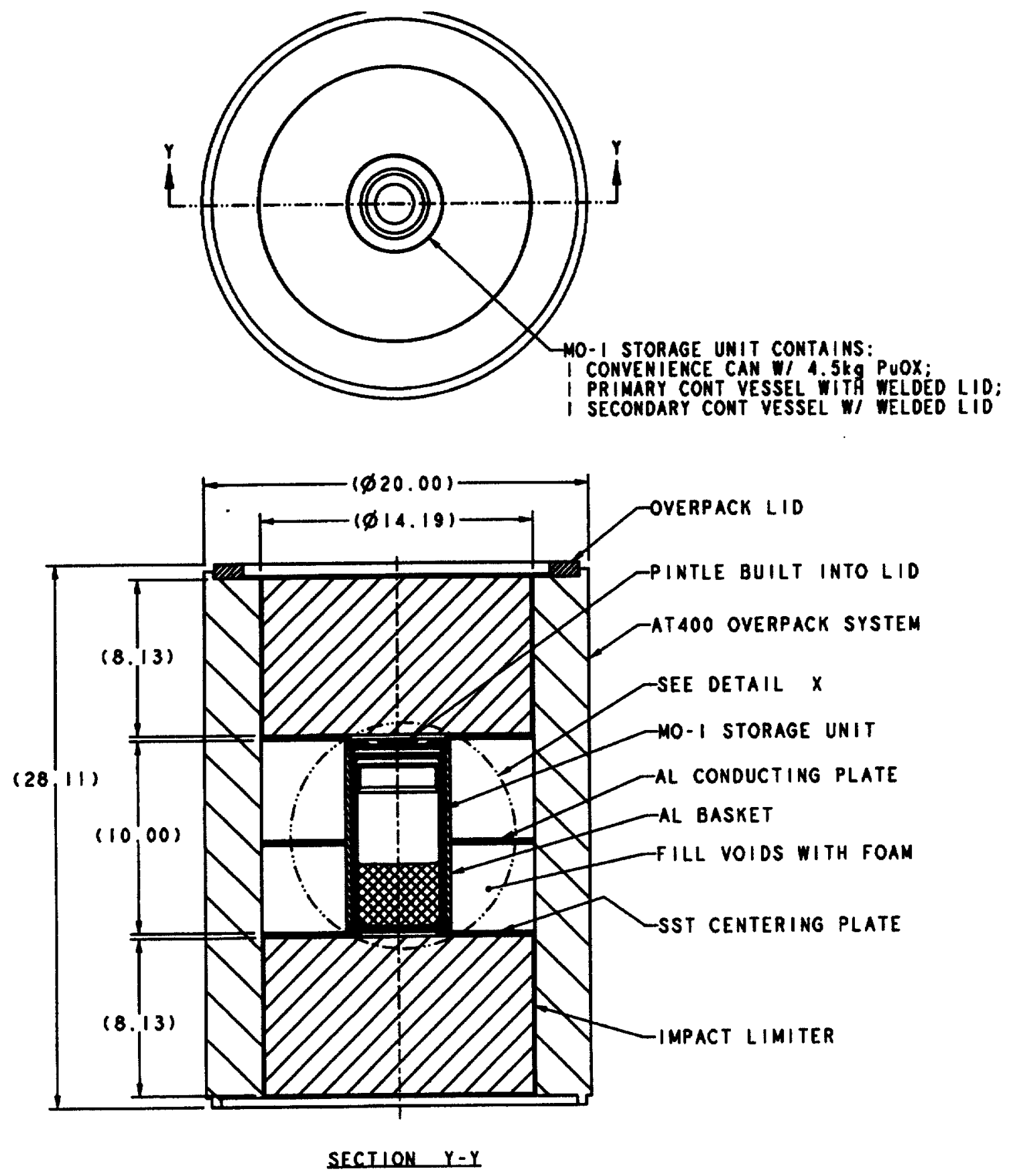

AT 400MO-I STORAGE PACKAGING

ESTIMATED WEIGHT $=257$ POUNDS

DRAWN: J. WATKINS $11-12-96$ 
Figure 2b. MO-1 Unit

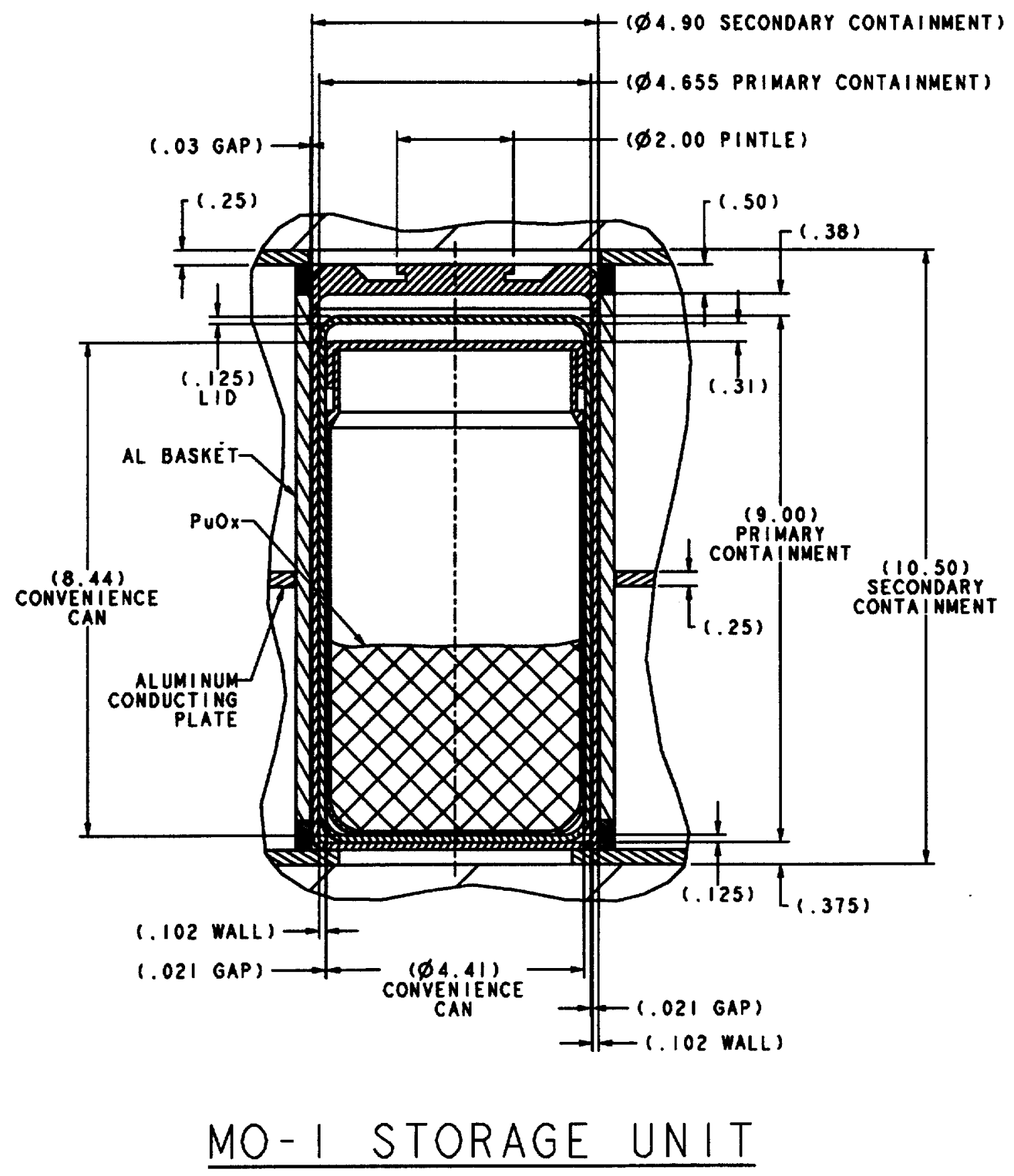


Figure 3a. AT-400MO-2 Storage Package
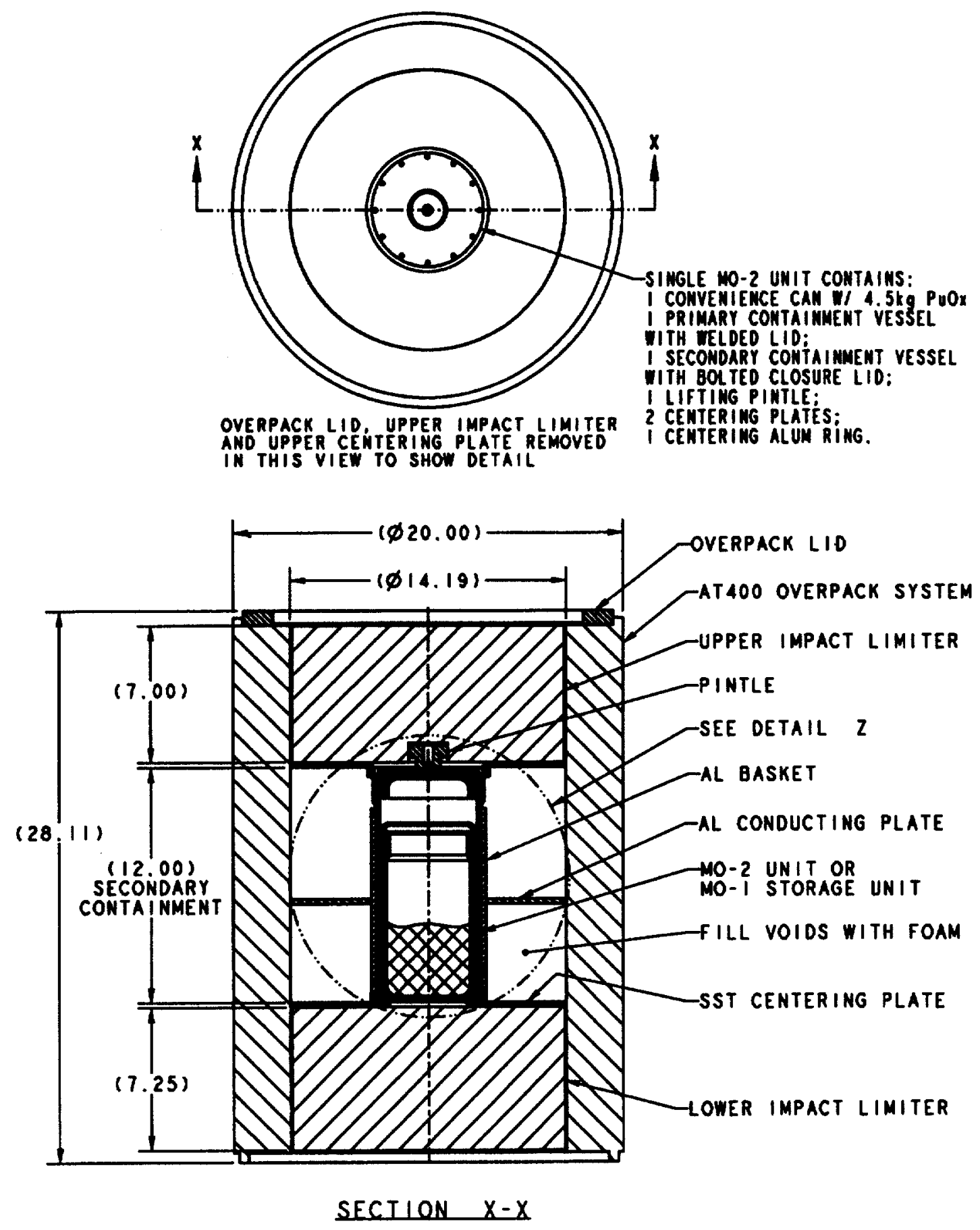

AT 40OMO-2 STORAGE AND TRANSPORT PACKAGING ESTIMATED WEIGHT $=273$ POUNDS

DRAWN: J. WATKINS II-13-96 
Figure 3b. MO-2 Unit

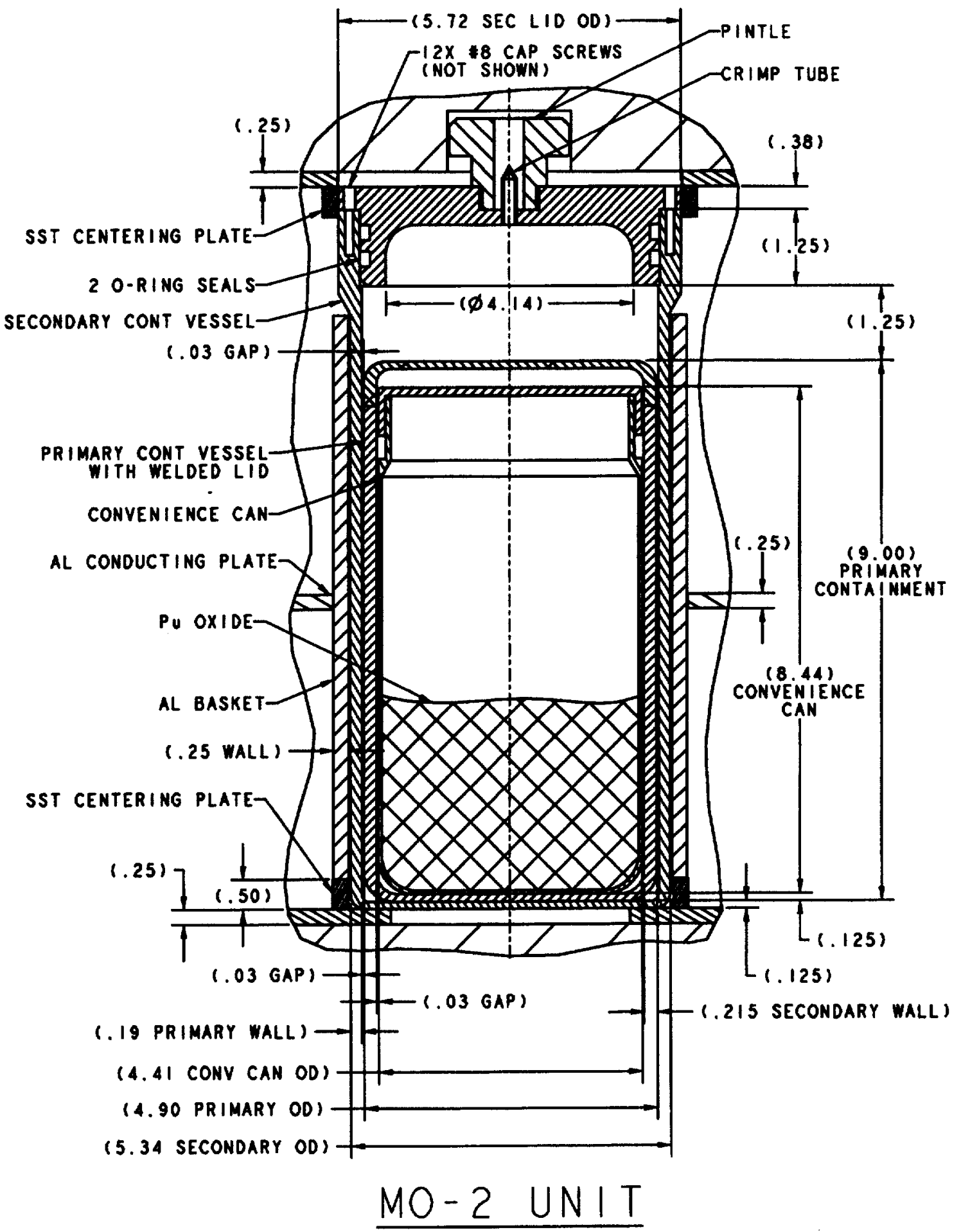


Figure 4a. AT-400MO-3 Storage Packaging

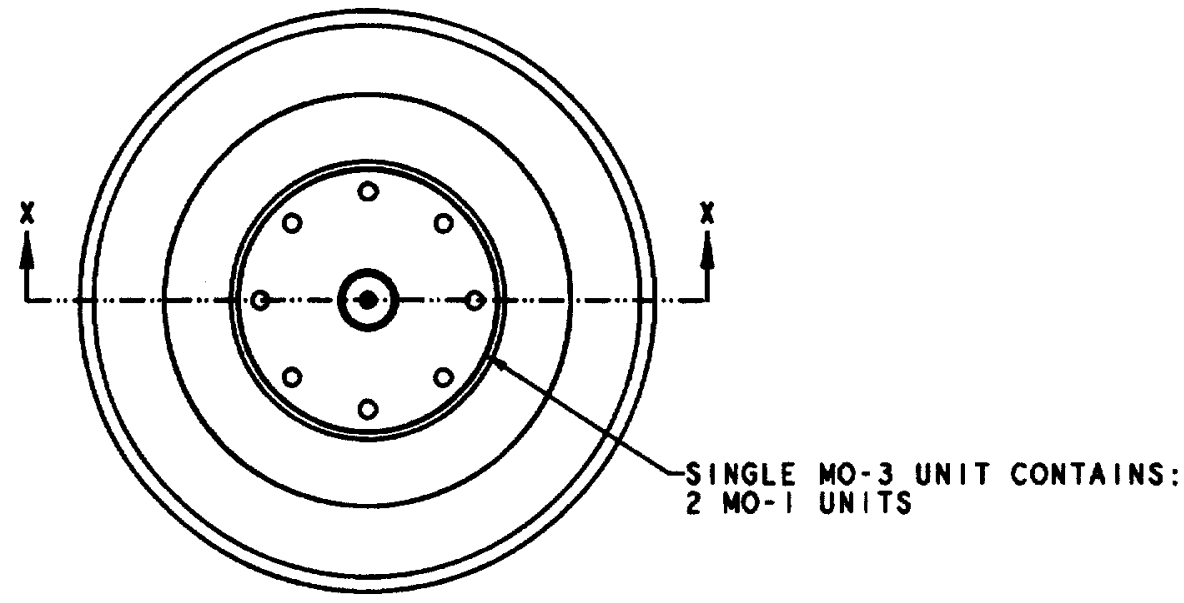

OVERPACK LIO, UPPER IMPACT LIMITER

AND UPPER CENTERING PLATE REMOVED

IN THIS VIEW TO SHOW DETAIL

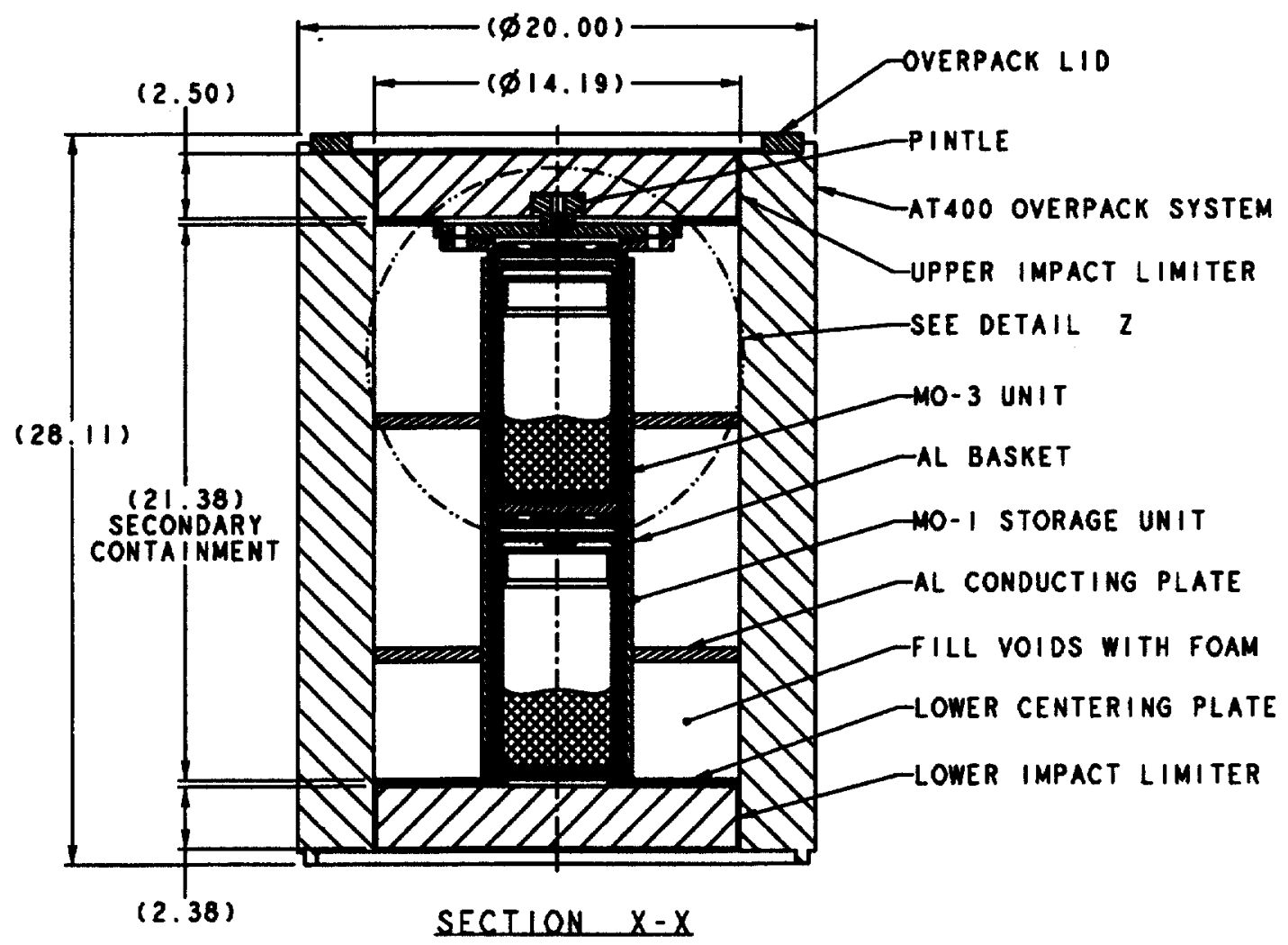

AT 4OOMO-3 STORAGE AND TRANSPORT PACKAGING ESTIMATED WEIGHT $=318$ POUNDS DRAWM: J. WATKINS II-13-96 
Figure 4b. MO-3 Unit

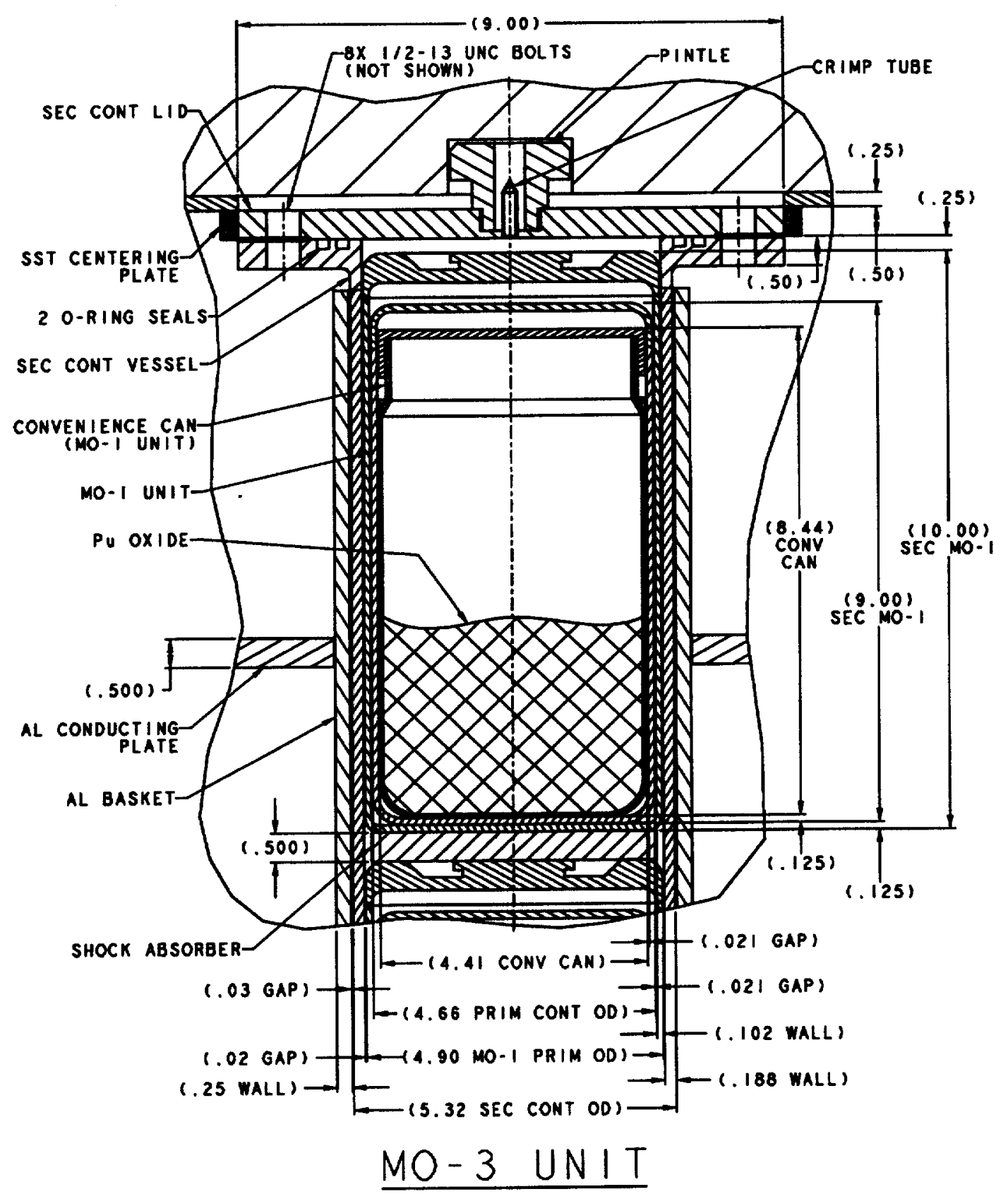


Figure 5a. AT-400MO-4 Storage Packaging
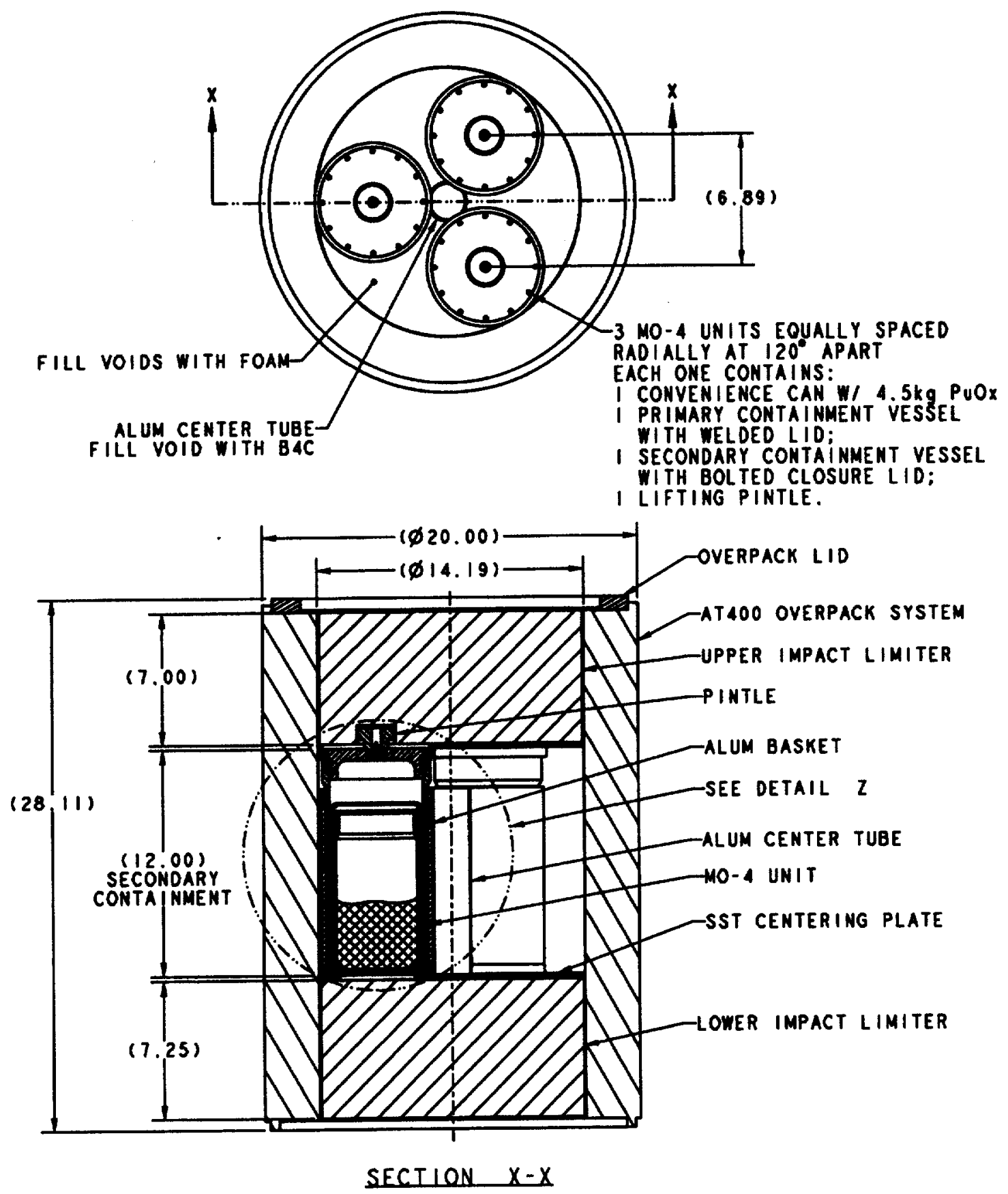

AT 40OMO-4 STORAGE AND TRANSPORTATION

ESTIMATED WE IGHT $=358$ POUNDS

DRAWN: J. WATKINS $11-13-98$ 
Figure 5b. MO-4 Unit

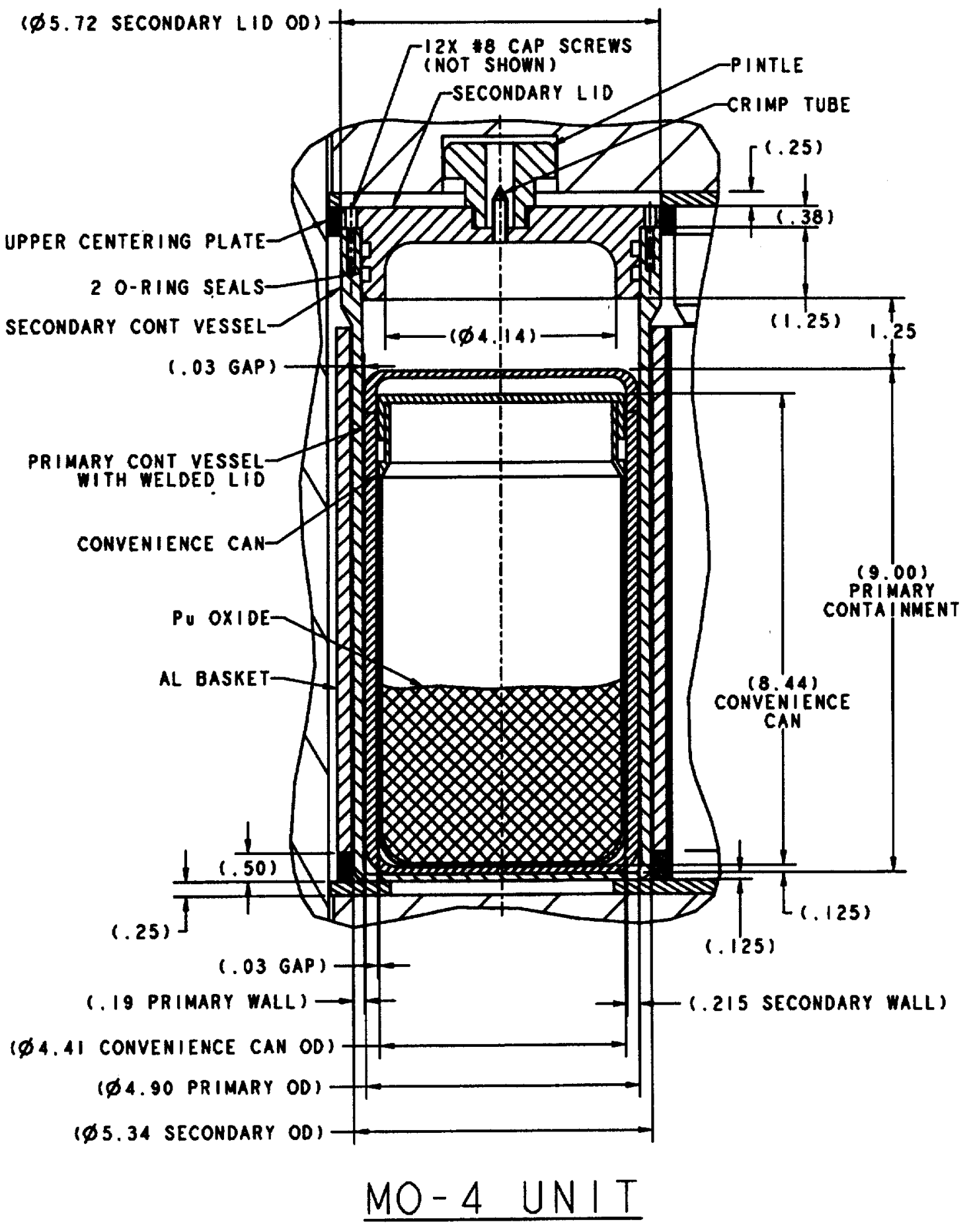




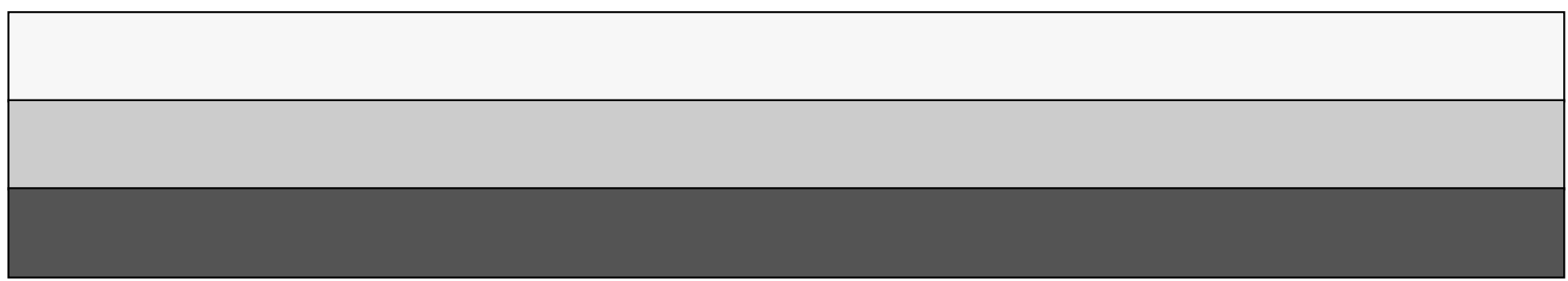

